\title{
The Antecedents, Consequences, and Mediating Role of Workload among Chinese Courier Drivers
}

\author{
Haitao Wen ${ }^{1}$, Hongduo Sun ${ }^{2}$, Sebastian Kummer ${ }^{1}$, Ben Farr-Wharton ${ }^{3}$ and David M. Herold ${ }^{4, *(D)}$ \\ 1 School of Management, Jilin University, Changchun 130022, China; wenht@jlu.edu.cn (H.W.); \\ sebastian.kummer@gmx.at (S.K.) \\ 2 Business School, Jilin University, Changchun 130012, China; sunhd19@mails.jlu.edu.cn \\ 3 Management at the School of Business and Law, Edith Cowan University, Perth 6004, Australia; \\ b.farrwharton@ecu.edu.au \\ 4 Institute of Transport and Logistics Management, Vienna University of Economics and Business, \\ Vienna 1020, Austria \\ * Correspondence: dherold@wu.ac.at
}

Citation: Wen, H.; Sun, H.; Kummer, S.; Farr-Wharton, B.; Herold, D.M. The Antecedents, Consequences, and Mediating Role of Workload among Chinese Courier Drivers.

Sustainability 2021, 13, 14015. https:// doi.org/10.3390/su132414015

Academic Editor: Natalio Extremera

Received: 26 November 2021

Accepted: 15 December 2021

Published: 19 December 2021

Publisher's Note: MDPI stays neutral with regard to jurisdictional claims in published maps and institutional affiliations.

Copyright: (c) 2021 by the authors. Licensee MDPI, Basel, Switzerland. This article is an open access article distributed under the terms and conditions of the Creative Commons Attribution (CC BY) license (https:// creativecommons.org/licenses/by/ $4.0 /)$.

\begin{abstract}
The growth of e-commerce in China can be regarded as a significant factor in the increase in occupational stress and the voluntary turnover of courier drivers. This paper aims to investigate selected occupational stress factors behind the turnover intentions of Chinese courier drivers. Using data from 229 couriers employed at the largest delivery companies in China, this study applies structural equation modelling to investigate not only the direct relationships between job-stress factors and turnover intentions but also the extent to which workload indirectly mediates turnover intentions among couriers. The results indicate that a combination of high workload with social stressors leads to turnover intentions. In particular, it was found that workload completely mediated the relationship between both the independent variables and the intention to leave the industry, suggesting that when workloads are high, the net effect of negative work experiences with regard to verbal aggression and ambiguous customer expectations increases the likelihood of an intention to leave the industry. Although restricted to China, this is one of the first studies investigating the effects of courier drivers' job stressors which highlights the importance of delivery companies working with staff to mitigate job stressors to reduce turnover intention.
\end{abstract}

Keywords: courier; occupational stress; turnover intention; China

\section{Introduction}

In recent years, e-commerce has grown rapidly in China and represents, with 40.1 billion delivered parcels in 2017, more than 50 percent of global deliveries [1]. This e-commerce growth also led to a growth in courier drivers by 130 percent between January 2014 and November 2017, bringing the total to more than 1.2 million Chinese courier drivers [2,3]. However, Chinese couriers are largely unskilled and face harsh working conditions with 25 percent of the couriers working more than $12 \mathrm{~h}$ per day, 7 days a week, delivering 150-300 parcels a day [4]. These conditions have led to high voluntary turnovers of couriers, with 50 percent leaving the courier job within a year and 80 percent between six months and three years [5].

Previous studies that have shown that occupational stress is a considerable determinant of turnover intention [6-9] and extensive research has been undertaken to investigate the occupational stress factors behind the voluntary turnovers and turnover intentions [10,11]. The most influential stress-related models, including the Karasek [12] demand-control model or the effort-reward imbalance model $[13,14]$, consist of specific predictors of occupational stress or other stress-related factors [15,16].

For example, a study found that the antecedents of occupational stress can be related to work overload, low social standing, or demanding social interactions, leading to 
turnover [17]. Other studies show that emotional and sentimental exhaustion, depersonalization, role ambiguity, and decline in self-fulfillment [18], as well as higher work demand and lower work autonomy, were associated with higher turnover intentions [6]. Cho and Lewis [19] argue that age and experience also lead to turnover intentions; thus, turnovers are shown to be particularly high among new workers.

However, most research was conducted in Western countries with a high degree of professional homogeneity in the sample selection [9,20-23]. Moreover, only a few studies have focused on the logistics sector and the courier, express, and parcel (CEP) industry [24-29]. As a consequence, research on occupational stress factors that may influence turnover intentions remains limited, particularly in a Chinese context. This paper aims to fill that gap by investigating selected occupational stress factors behind the turnover intentions of Chinese courier drivers.

In order to analyze the factors behind the turnover intentions, a survey was conducted among the seven most influential CEP companies in China. Using a mediation model to test the direct and indirect relationships between job stressors (verbal aggression, ambiguous customer expectations, and workload) and turnover intentions, this paper attempts to provide meaningful insight into the correlation between customer-related and non-customer-related job stressors and turnover intentions.

In particular, the contribution of this study is threefold. First, as most research focuses on Western countries, the study will provide insights into the Chinese market. Second, the study will focus specifically on courier, express, and parcel (CEP) companies, thereby contributing to the knowledge in this under-researched area regarding voluntary turnover. Third, this paper will highlight the relevant factors and relationships behind turnover intentions, thereby providing a theoretical foundation for researchers and managers to develop tools for human resource (HR) management.

This paper is structured as follows: in the next section, we provide an overview about the occupational stress factors, present the structural model, and develop the hypotheses. This is followed by the methodology and subsequently, in the next section, the analysis and the presentation of the results. Then, the results are discussed, and we conclude with a summary of the results, highlight the limitations of the study, and suggest future research directions.

\section{Occupational Stress Factors in the Logistics Industry}

The CEP industry in China is a labor-intensive industry and courier drivers-as frontline workers-represent a crucial role in the delivery process. In addition, although technological developments have made a considerable contribution to the logistics industry [30-37], delivering parcels in China does not seem to be an easy task: the China Federation of Logistics \& Purchasing [38] found that the number of parcels that need to be delivered often exceeds an average of 150 packs per day with almost 40 percent of the couriers working more than ten hours a day in a six-day week. This workload may lead to increased job or occupational stress, which is defined as having physiological as well as physical impacts on workers, including mental, physical, or emotional burdens involving work [39] and takes place when there is a divergence between the workplace demand and the capability of the person to execute the demands [40].

Scholars found that occupational stress negatively affects customer service (Karatepe et al., 2009) and the work performance of frontline service workers [41-45]. However, as frontline service workers represent a crucial part of service companies, understanding the related occupational stress antecedents and consequences can be regarded as a critical field for scholars and managers in their respective HR agendas [46]. The courier drivers' frequent intense face-to-face interactions with clients are important touchpoints during a delivery. However, the delivery handover does not require the final customer to be respectful or polite and courier drivers are expected to deliver parcels to all clients, including impolite, insulting, and even abusive customers [47]. Within the hospitality industry, Harris and Reynolds [48] found that up to 70 percent of clients mistreated frontline service workers 
verbally and intentionally for financial benefits. Thus, philosophies such as 'the customer is king' and 'the customer is always right' represent an uneven relationship between clients and frontline workers [49], requiring, for example, courier drivers 'to serve customers with a smile' even when subject to verbal aggression. Moreover, customers may have ambiguous expectations that are largely outside of the company's control but have a considerable impact on the frontline workers' stress [50].

Given long working times and high pressure to deliver packages, the workload of couriers in China may exacerbate occupational stress, potentially resulting in higher worker turnover [51-54]. Turnover intention in our context can be defined as the staff member's idea of quitting, the intention to look for other jobs, or the opportunity of a new job [55]. However, while some existing research indicates significant links between occupational stress and turnover intentions within the service industry [56,57], other articles found no or little correlation between stress and turnover intention [58]. This lack of clarity in the research findings and the limited knowledge in the area of courier drivers, particularly in China, warrant further examination to fully understand the job-stress determinants driving turnover intentions. As such, the aim of this paper is to examine the relationships between job stressors and turnover intentions in the logistics industry among courier drivers in China. In particular, the direct and indirect relationships between customer-related social stressors and non-customer-related job stressors are investigated to provide insight into the factors that drive turnover intentions.

\subsection{Conceptual Model}

The model includes customer-related social stressors (CSS), namely verbal aggression and ambiguous customer expectations and non-customer-related job stressors, namely the respective workload of the courier. However, we use a mediation model to test (a) the direct relationships between job stressors (verbal aggression, ambiguous customer expectations, and workload) and turnover intentions and (b) the indirect relationships, i.e., a combination of customer-related and non-customer-related job stressors, i.e., the relationship between the customer-related social stressors and workload as a mediator, as well as the relationship between turnover intentions and workload as a mediator.

Based on the extant literature, we posit for the direct relationships that the couriers' job stressors, namely verbal aggression, ambiguous customer expectations, and workload, exacerbate the intention to leave the industry. However, although we also expect that a combination of customer-related and non-customer-related job stressors also exacerbate the intention to leave the industry, we test to what extent workload as a mediator impacts turnover intentions. The next sections derive the hypotheses with regard to the linkages among the study variables.

\subsection{Hypotheses Development}

\subsubsection{Customer-Related Job Stressors}

To understand the drivers behind the couriers' turnover intentions, we incorporated CSS in our model (see Figure 1), which includes "a class of characteristics, situations, episodes, or behaviors that are related to psychological or physical strain and that are somehow social in nature" [50]. In particular, we examine two dimensions of CSS as job stressors identified by Dormann and Zapf [50]: (1) ambiguous customer expectations, and (2) verbal aggression.

The first factor is attributed to unclear and ambiguous customer expectations. Scholars point out the similarity of this factor to the construct of role ambiguity, as well as to the construct of the uncertainty of goal attainment [59-61]. Role ambiguity has a negative relation to job performance, which was in turn associated with turnover intentions [57,62]. Often, role ambiguity and uncertainty are discussed within the context of cognitive aspects, whereas ambiguous customer expectations are linked to the emotional and social implications of this ambiguity. Aggressive behavior and conflicts may harm not only the information exchange, but also the cooperative intentions between customers and courier 
drivers. Thus, a correlation between ambiguous customer expectations and turnover intention can be expected.

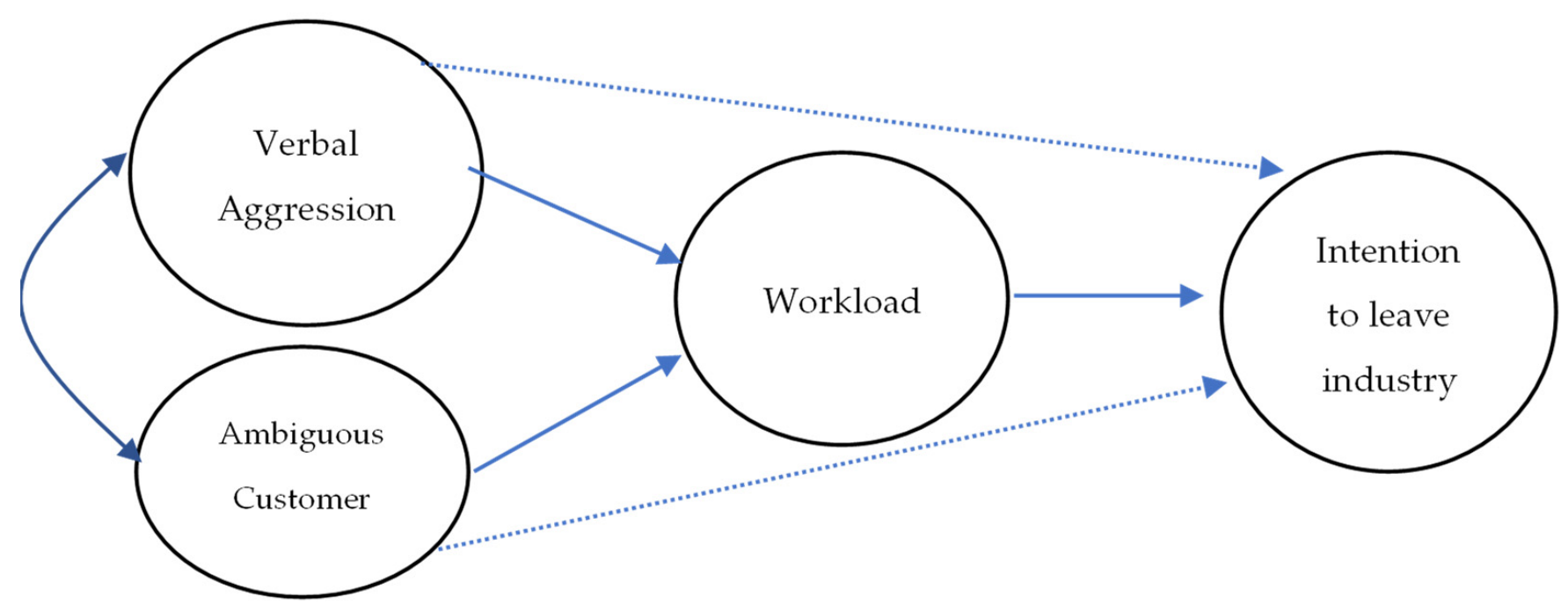

Figure 1. Path model.

Hypothesis 1 (H1). Ambiguous customer expectations are positively associated with intention to leave the industry.

The second factor is attributed to the customers' verbal aggression and is related to antisocial behavior and workplace aggression [63]. In particular, verbal aggression is intended to harm another person and his or her self-esteem [64]. Several studies [65-69] have shown that verbal aggression from customers can be a severe stressor. For example, $\mathrm{Li}$ and Zhou [70] argue that the verbal aggression of customers has a significant impact on turnover intentions in call centers. Often, frontline workers are more exposed to interactions with their clients' customers. These happen more frequently than with supervisors and colleagues, such as courier drivers in the logistics industry. Thus, we expect that customer verbal aggression exacerbates occupational stress levels and leads to higher turnover intentions among couriers.

Hypothesis 2 (H2). Verbal aggression is positively associated with intention to leave the industry.

\subsubsection{Non-Customer-Related Job Stressors}

In addition, service industries are labor-intensive industries [71]. Increasing the workload or the perceived workload of frontline workers or couriers generates job stress [72] and may negatively affect performance and organizational commitment [46,73,74]. Dollard et al. [75] found that a high workload in combination with low rewards is linked to low job satisfaction and sickness absence, while Kim et al. [76] and Duraisingam et al. [77] illustrate that job stress and a heavier workload escalate turnover ratios. Therefore, we expect that a higher workload leads to higher turnover intentions among couriers.

Hypothesis 3 (H3). Workload is positively associated with intention to leave the industry.

So far, it is not clear to what extent the respective courier workload may mediate turnover intentions among couriers. Scholars have found that higher workloads may exacerbate turnover intentions, but low or lower workload may also help to mitigate other negative work experiences $[19,21,26,78,79]$. According to the 'Conservation of Resources' Theory [15], a high workload can also be seen as a resource loss, while a low workload can be seen as a resource gain. A resource loss, i.e., a high workload, however, is "dis- 
proportionally more salient than a resource gain" [16], meaning that a loss-or in our context a high workload-has a significantly greater impact on turnover intentions. To clarify the nature of the correlation between turnover intentions and the customer-related job stressors, we propose that workload as mediator leads to a better clarification of the correlation between the turnover intentions and the customer-related job stressors, leading to hypotheses four and five:

Hypothesis $4 \mathbf{( H 4 ) . ~ W o r k l o a d ~ m e d i a t e s ~ t h e ~ r e l a t i o n s h i p ~ b e t w e e n ~ v e r b a l ~ a g g r e s s i o n ~ a n d ~ i n t e n t i o n ~}$ to leave the industry.

Hypothesis 5 (H5). Workload mediates the relationship between ambiguous customer expectations and intention to leave the industry.

The relationships to be tested in this paper are depicted in the path model in Figure 1.

\section{Methodology}

\subsection{Measures}

We used the existing literature to determine the scale items in this study. For the CSS, comprising ambiguous customer expectations and customer verbal aggression, we adopted selected items from Dormann and Zapf [50]. In particular, ambiguous customer expectations (e.g., "Customers change their requests which makes my work more complicated") included four items, while customer verbal aggression was operationalized using three items (e.g., "Customers often shout at us"). To measure the non-customer-related job stressor, workload was also operationalized via a three-item scale (e.g., "I send and receive a large number of parcels combined with heavy work and tight schedules"), while turnover intention was operationalized via eight items (e.g., "I often think about leaving the job").

Following Dormann and Zapf [50], we documented the survey responses for the CSS items using a 5-point Likert scale range from 1 ("not at all true") to 5 ("absolutely true"). In addition, background data were also collected, including work-related information, working years in the CEP industry, the name of the courier company, the working status, and the monthly income, which were used as control variables. In particular, these control variables were measured as follows: monthly income was scaled as: $1=$ below CNY 3000; 2 = CNY 2001-4000; 3 = CNY 4001-6000; 4 = CNY 6001-8000; and $5=$ more than CNY 8000. There were 229 companies sampled in the research, and these were numbered 1, 2, 3, and 4 (up to 229) and assigned to each respondent according to the company they worked for. Moreover, we used six points on a scale to represent the length of time a respondent had worked for the courier company: 1 = less than half a year, 2 = half a year to one year, $3=1-3$ years, $4=4-6$ years, $5=7-10$ years, and $6=$ more than 10 years.

\subsection{Sample and Data Collection}

Data collection took place using a survey at the seven largest companies in China's domestic CEP industry, namely ZTO Express, YTO Express, STO Express, BEST Express, YUNDA Express, S.F. Express, and JD Logistics. Frontline managers of the respective companies distributed the surveys, including a cover letter to drivers, who in turn distributed the surveys to potential participants. Participants then returned the completed surveys in a sealed envelope to the driver and subsequently to the managers. Participants were assured of the confidentiality of their personal information.

A total of 700 surveys were distributed across the seven companies. Of the 700 questionnaires, 314 (total return rate: 44.9 percent) were returned. Eighty-five of the questionnaires were not considered because they were incomplete. Finally, 229 surveys were coded for data analysis, thus leading to an effective response rate of 32.7 percent. 


\subsection{Data Analysis}

The data were analyzed by a two-step approach: first, the measurement model was estimated through confirmatory factory analysis (CFA) using AMOS 25, followed by a structural model analysis.

\section{Results}

\subsection{Confirmatory Factor Analysis}

A confirmatory factor analysis with the aforementioned variables was assembled in the AMOS 25 structural equation modelling program. As displayed in Table 1, the initial model fit was acceptable against the standard thresholds purported by Hair et al. [80]. Yet, the modification indices suggested that the model could be substantially improved if a covariance was added between the first and second items for ambiguous customer expectations. This was a model in a second iteration of the confirmatory factor analysis (termed 'final CFA with Modification Indices') in Table 1. Given that this model displayed a number of optimal indicators against set thresholds, it was retained in the path-model analysis.

Table 1. Confirmatory factor analysis.

\begin{tabular}{cccc}
\hline & Initial CFA & Final CFA with Modification Indices & Final Path Model \\
\hline $\mathrm{X}^{2} / \mathrm{DF}^{1}$ & 2.159 & 1.677 & 1.576 \\
\hline $\mathrm{CFI}$ & \\
\hline $\mathrm{TLI}$ & 0.949 & 0.971 & 0.971 \\
\hline $\mathrm{RMSEA}^{3}$ & 0.935 & 0.962 & 0.963 \\
\hline
\end{tabular}

${ }^{1}$ The Chi-Square over Degrees of Freedom ( $\left.\mathrm{X}^{2} / \mathrm{DF}\right)$ is acceptable when below 5, but optimal when below 2. ${ }^{2}$ The Corrected Fit Index (CFI) and Tucker-Lewis Index (TLI) are acceptable when over 0.9, but optimal when over 0.95 .

${ }^{3}$ The root-mean square error approximation is acceptable when under 0.8 , but optimal when under 0.5 .

Scale reliability, as well as discriminant and convergent validity was evidenced (see Table 2). The composite reliability of all scales was above the 0.7 threshold; the average variance extracted was greater than 0.5 , and the maximum shared variance was less than the average variance extracted.

Table 2. Reliability and validity.

\begin{tabular}{cccc}
\hline & $\begin{array}{c}\text { Composite } \\
\text { Reliability }\end{array}$ & $\begin{array}{c}\text { Average } \\
\text { Variance } \\
\text { Extracted }\end{array}$ & $\begin{array}{c}\text { Maximum } \\
\text { Shared } \\
\text { Variance }\end{array}$ \\
\hline 1. Intention to Leave Industry & 0.847 & 0.583 & 0.312 \\
\hline 2. Verbal Aggression & 0.822 & 0.607 & 0.312 \\
\hline 3. Ambiguous Customer Expectations & 0.857 & 0.611 & 0.097 \\
\hline 4. Workload & 0.848 & 0.652 & 0.272 \\
\hline
\end{tabular}

Given that the model displayed the optimal model fit, and the scale reliability and validity was robust, a path model was assembled.

\subsection{Structural Model and Hypotheses Tests}

Using SEM, we used a set of indices to test the structural model and hypotheses (see Figure 2). The structural model helped to examine the predictive power of ambiguous customer expectations and verbal aggression on turnover intentions as well as the mediating role of the respective workload. Monthly income, the company the respondent worked for, and the years working for the company were used as control variables, none of which had a significant relationship. 


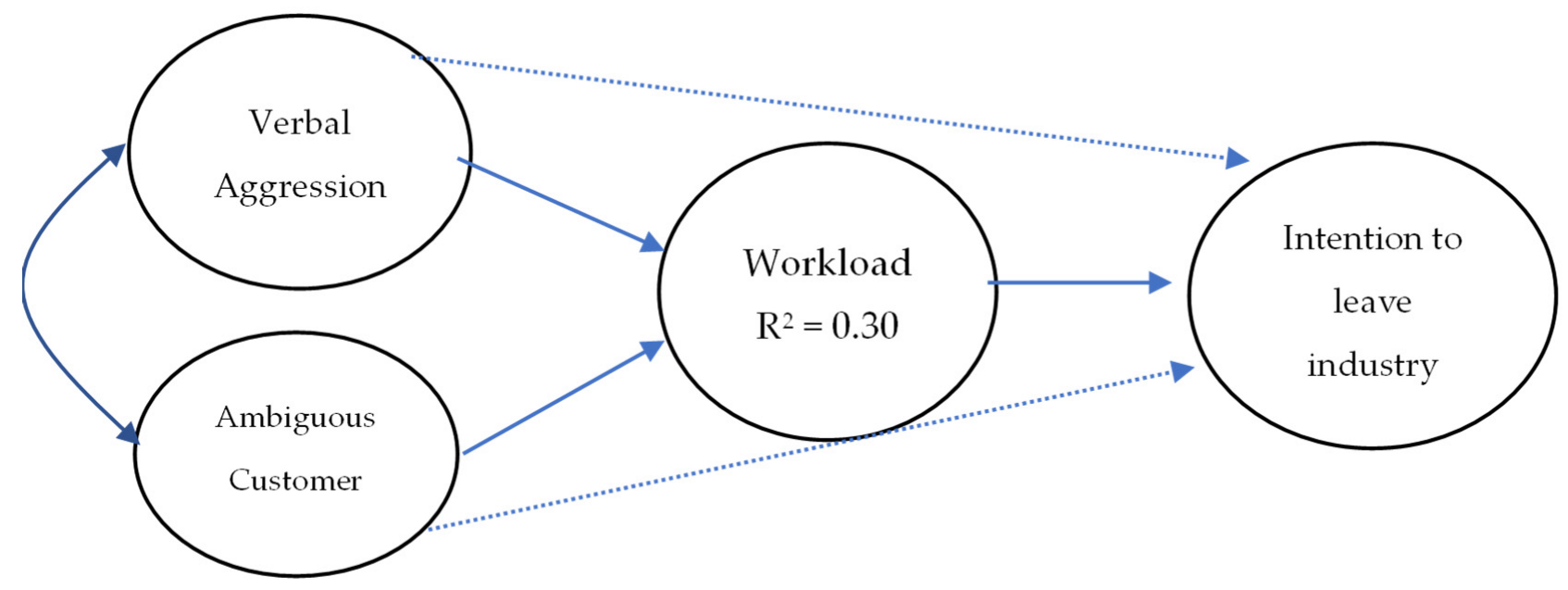

Figure 2. Path model results: $\mathrm{N}=229$, significant paths $(p<0.05)$ are displayed in blue, mediated paths are indicated by a dotted line.

To test the mediation effect of workload, direct and indirect modelling were undertaken using the bootstrap technique at the $95 \%$ confidence interval. The direct and indirect paths are displayed in Table 3.

Table 3. Direct and Indirect Modelling using the Bootstrap 95\% confidence technique.

\begin{tabular}{cccc}
\hline & Direct & Indirect & Conclusion \\
\hline Verbal Aggression $\rightarrow$ Workload & $0.47^{*}$ & - & Direct \\
\hline $\begin{array}{c}\text { Verbal Aggression } \rightarrow \text { Intention to } \\
\text { leave industry }\end{array}$ & 0.41 (N.S.) & $0.10^{*}$ & Complete mediation \\
\hline $\begin{array}{c}\text { Ambiguous customer expectation } \rightarrow \\
\text { workload }\end{array}$ & $0.17^{* *}$ & - & Direct \\
\hline $\begin{array}{c}\text { Ambiguous customer expectation } \rightarrow \\
\text { Intention to leave industry }\end{array}$ & 0.12 (N.S.) & $0.04^{*}$ & Complete Mediation \\
\hline $\begin{array}{c}\text { Workload } \rightarrow \text { Intention to leave } \\
\text { industry }\end{array}$ & $0.22 *$ & - & Direct \\
\hline $\begin{array}{c}\text { Ambiguous Customer Expectation } \\
\leftrightarrow \text { Verbal Aggression }\end{array}$ & $0.30 * *$ & - & Direct \\
\hline
\end{tabular}

Regarding the hypotheses, the analysis suggested that verbal aggression and ambiguous customer expectations were significantly related to turnover intentions, and this was fully mediated through the workload construct; thus, support was found for all five hypotheses. Table 4 provides a breakdown of the results by hypothesis.

Table 4. Results by hypothesis.

\begin{tabular}{ccc}
\hline Hypotheses & Paths & Results \\
\hline $\begin{array}{c}\text { Hypothesis 1: } \\
\text { Ambiguous customer expectation is } \\
\text { positively associated with intention to leave } \\
\text { industry. }\end{array}$ & $\begin{array}{c}\text { Direct path } \beta=0.12 p=\text { not significant; } \\
\text { Indirect path } \beta=0.04, p<0.05 .\end{array}$ & $\begin{array}{c}\text { supported } \\
\text { (mediated path through workload) }\end{array}$ \\
\hline $\begin{array}{c}\text { Hypothesis 2: } \\
\begin{array}{c}\text { Verbal aggression is positively associated } \\
\text { with intention to leave the industry. }\end{array}\end{array}$ & $\begin{array}{c}\text { Direct path } \beta=0.41 p=\text { not significant; } \\
\text { Indirect path } \beta=0.10, p<0.05 .\end{array}$ & $\begin{array}{c}\text { supported } \\
\text { (mediated path through workload) }\end{array}$ \\
\hline
\end{tabular}


Table 4. Cont

\begin{tabular}{ccc}
\hline Hypotheses & Paths & Results \\
\hline $\begin{array}{c}\text { Hypothesis 3: } \\
\text { Workload is positively associated with } \\
\text { intention to leave the industry. }\end{array}$ & Direct path $\beta=0.22 p<0.05$ & $\begin{array}{c}\text { supported } \\
\text { (direct path) }\end{array}$ \\
\hline $\begin{array}{c}\text { Hypothesis 4: } \\
\text { Workload mediates the relationship between } \\
\text { verbal aggression and intention to leave the } \\
\text { industry. }\end{array}$ & $\begin{array}{c}\text { Mediation pathway is Indirect path } \beta= \\
0.10, p<0.05 .\end{array}$ & supported \\
\hline $\begin{array}{c}\text { Hypothesis 5: } \\
\begin{array}{c}\text { Workload mediates the relationship between } \\
\text { ambiguous customer expectations and } \\
\text { intention to leave industry. }\end{array}\end{array}$ & $\begin{array}{c}\text { Mediation pathway is Indirect path } \beta= \\
0.04, p<0.05 .\end{array}$ \\
\hline
\end{tabular}

\section{Discussion}

As Chinese courier drivers have more frequent interactions with clients than with their supervisors, these interactions can be regarded as an essential factor. The results show that non-customer-related and customer-related job stressors influence turnover intentions, i.e., the hypotheses, both for ambiguous customer expectations and verbal aggression, were supported. In other words, the courier drivers' frequent face-to-face interactions with their customers in combination with a high workload result in occupational stress and turnover intentions.

As such, this study makes a considerable contribution to the literature on turnover intentions in Chinese CEP companies from a theoretical point of view. So far, the majority of stress-related research has examined the aggressive behavior of work colleagues and supervisors or task-related intra-organizational workplace stressors, such as job demands, or physical and social factors $[10,53,63,81]$. To date, empirical results from studies investigating job stressors from customers in service companies and the mediating role of workload among courier drivers is limited. By addressing this gap, this paper examines the job stressors of Chinese courier drivers, thereby providing insights into the relationship between customer-related and non-customer-related job stressors and turnover intentions.

From a practical point of view, companies in the CEP industry need to work with staff to be able to mitigate and manage ambiguous customers and verbal aggression to minimize the effect on turnover intention. As the job stressors, ambiguous customer expectations or verbal aggression represent an unavoidable factor for frontline workers which cannot be eliminated [64]. We found that managers have mainly three options to reduce the effect of the job stressors.

First, HR managers may develop coping systems through training programs and newly introduced policies and rules. Reynolds and Harris [82] found that frontline workers confronted with abusive customer behavior often manage the job stress poorly and engage in risky coping mechanisms, such as drinking and smoking, ignoring or bribing customers, or even seeking retribution. For a thorough coping system, clear and comprehensible written policies on how to differentiate reasonable customer behavior and demands from unreasonable customers not only provide a guidance on the company's expectations to courier drivers, but also gives them instructions on how to manage the customer. A clear policy would indicate if a customer was unreasonable so that the behavior could be reported and dealt with by the supervisors. Greater support from supervisors seems also to be particularly important in a Chinese context [83]. The existing literature argues that Chinese workers see supervisors as central points of contact and are more loyal to their specific supervisor than to the organization [84-86]. This attitude to loyalty may also influence turnover intentions, as reciprocity (or "Pao" in Chinese), i.e., the payback for a good deed, plays a significant role in Chinese traditional culture and tends to have a considerable impact on the Chinese behavior and attitudes $[87,88]$. 
Second, policies and rules may also include empowerment practices to immediately handle customer complaints. This would not only help to potentially increase customer satisfaction but would also help to increase the rank of the courier drivers. In a Chinese context, courier drivers are regarded as having lower prestige than other worker cohorts [89] and without empowerment courier drivers cannot offer solutions according to the "customer is king" and "customer is always right" philosophy, which leads to an uneven relationship between courier drivers and their clients. By handing empowerment practices to the frontline, courier drivers have more options to defend themselves against difficult customers and deflect verbal aggression [90], and it shows the organization's trust in the courier driver, which may help to mitigate turnover intention.

Third, training programs may focus on developing interpersonal skills. A courier driver's task is multidimensional, e.g., the courier driver should not only manage the customer interactions effectively, but understand and respond to difficult customer requests and show a friendly and customer-oriented attitude in order to gain or keep loyal customers. As such, the developing of interpersonal skills goes beyond a positive attitude and aims at controlling customer interactions and dealing with difficult behavior as well as advancing their technical skills [91,92], thereby focusing on the prevention of confrontations rather than reactions to customers.

\section{Conclusions}

We set out to test a model to analyze the structural relationships among job stressors and the antecedents such as CSS (ambiguous customer expectations, verbal aggression), as well as workload as a non-customer-related stressor and its impact on turnover intentions among courier drivers from the largest seven CEP companies in China. Using customerrelated and non-customer-related job stressors and workload as a job stressor and as a mediator, we built a mediation model to examine their impact on the outcome variable of turnover intention. We found that verbal aggression and ambiguous customer expectations were significantly related to turnover intentions, and this was fully mediated through the workload construct; thus, support was found for all five hypotheses.

The results show that Chinese courier drivers are expected to perform heavy social and physical work. Understanding their job stressors is an essential human resource matter as it is ultimately related to the long-term survival of companies and their organizational performance. As such, the results of this paper may provide a theoretical foundation for voluntary turnover research in and beyond Chinese CEP companies, particularly with regard to customer-related and non-customer-related job stressors. In particular, we presented three implications for Chinese CEP companies:

First is the development of coping systems through training programs and newly introduced policies and rules, such as clear and comprehensible written policies and greater support from supervisors. Second is the introduction of empowerment practices to increase the rank of the courier drivers, which shows the organization's trust and may help to mitigate turnover intention. Third is the development of interpersonal skills to better react to difficult customer requests or even prevent confrontations.

While our results present particular value to scholars and practitioners in the Chinese delivery companies, this paper has several limitations. First, we used only one specific industry of one particular country, thus the results may be influenced by the country's social culture. While this may limit the generalizability of the findings, this paper extends the knowledge on occupational stress and turnover intentions by examining job stressors in the CEP industry. So far, most empirical research has focused on Western industries and companies. We invite researchers to test the model in other industries or companies. Future research might also include investigations to verify or contradict our results in the setting of another country. Second, our survey involved a structured questionnaire, therefore presenting the rather limited scope typical for questionnaires. Future researchers may include open-ended questions to better understand the background of these questions. 
Moreover, we used only two customer-related job stressors; thus, future research could expand the job stressors to further redefine the factors for turnover intention.

Author Contributions: Contributions: H.W. and H.S. designed the work, analyzed the data, and drafted the work; S.K. and D.M.H. revised the work; B.F.-W. analyzed and interpreted the data. All authors have read and agreed to the published version of the manuscript.

Funding: This research received no external funding.

Institutional Review Board Statement: Not applicable.

Informed Consent Statement: Not applicable.

Data Availability Statement: The datasets used and/or analyzed during the current study are available from the corresponding author on reasonable request.

Conflicts of Interest: The authors declare no conflict of interest.

\section{References}

1. Wallace, C.; Pitney, B. Parcel Shipping Index Reports Global Parcel Shipping Reaches \$279 Billion in Revenue. Business Wire 2018. Available online: https:/ / www.businesswire.com/news/home/20180828005237/en/ (accessed on 6 August 2019).

2. China Daily. China's Express Delivery Firms See Rapid Growth in China Daily 2018. Available online: http:/ / www.chinadaily.com. $\mathrm{cn} / \mathrm{a} / 201801 / 13 /$ WS5a59ef62a3102c394518f090.html (accessed on 11 September 2019).

3. Mcmorrow, R. For Couriers, China's E-Commerce Boom Can Be a Tough Road; The New York Times: Manhattan, NY, USA, 2018. Available online: https://www.nytimes.com/2017/01/31/business/china-courier-delivery-labor.html?_r=0 (accessed on 6 August 2019).

4. AliResearch. National Social E-commerce Logistics Practitioner Research Report. 2016. Available online: http:/ /www.aliresearch. $\mathrm{com} / \mathrm{blog} /$ article/detail/id/20922.html (accessed on 23 January 2019).

5. Hou, L. Couriers Being Driven to Despair; China Daily: Chaoyang, Beijing, 2017. Available online: http://www.chinadaily.com.cn/ china/2017-02/03/content_28088553_3.htm (accessed on 6 August 2019).

6. Chen, J.-C.; Silverthorne, C. The impact of locus of control on job stress, job performance and job satisfaction in Taiwan. Leadersh Organ. Dev. J. 2008, 29, 572-582. [CrossRef]

7. Gaither, C.A.; Kahaleh, A.A.; Doucette, W.R.; Mott, D.A.; Pederson, C.A.; Schommer, J.C. A modified model of pharmacists' job stress: The role of organizational, extra-role, and individual factors on work-related outcomes. Res. Soc. Adm. Pharm. 2008, 4, 231-243. [CrossRef]

8. Hersey, P.; Blanchard, K. Organizational Behaviour; Prentice Hall: Englewood Cliffs, NJ, USA, 1988.

9. Rubenstein, A.L.; Eberly, M.B.; Lee, T.W.; Mitchell, T.R. Surveying the forest: A meta-analysis, moderator investigation, and future-oriented discussion of the antecedents of voluntary employee turnover. Pers. Psychol. 2018, 71, 23-65. [CrossRef]

10. Lee, T.W.; Mitchell, T.R. An alternative approach: The unfolding model of voluntary employee turnover. Acad. Manag. Rev. 1994, 19, 51-89. [CrossRef]

11. Hom, P.W.; Mitchell, T.R.; Lee, T.W.; Griffeth, R.W. Reviewing employee turnover: Focusing on proximal withdrawal states and an expanded criterion. Psychol. Bull. 2012, 138, 831-858. [CrossRef]

12. Karasek, R.A., Jr. Job Demands, Job Decision Latitude, and Mental Strain: Implications for Job Redesign. Adm. Sci. Q. 1979, 24, 285-308. [CrossRef]

13. Niedhammer, I.; Tek, M.-L.; Starke, D.; Siegrist, J. Effort-reward imbalance model and self-reported health: Cross-sectional and prospective findings from the GAZEL cohort. Soc. Sci. Med. 2004, 58, 1531-1541. [CrossRef]

14. Siegrist, J. Adverse health effects of high-effort/low-reward conditions. J. Occup. Health Psychol. 1996, 1, 27. [CrossRef]

15. Hobfoll, S.E. Conservation of resources: A new attempt at conceptualizing stress. Am. Psychol. 1989, 44, 513. [CrossRef]

16. Hobfoll, S.E. The influence of culture, community, and the nested-self in the stress process: Advancing conservation of resources theory. Appl. Psychol. 2001, 50, 337-421. [CrossRef]

17. Schaufeli, W.B.; Peeters, M.C.W. Job Stress and Burnout Among Correctional Officers: A Literature Review. Int. J. Stress Manag. 2000, 7, 19-48. [CrossRef]

18. Kang, H.J.; Gatling, A.; Kim, J. The impact of supervisory support on organizational commitment, career satisfaction, and turnover intention for hospitality frontline employees. J. Hum. Resour. Hosp. Tour. 2015, 14, 68-89. [CrossRef]

19. Cho, Y.J.; Lewis, G.B. Turnover intention and turnover behavior: Implications for retaining federal employees. Rev. Public Pers. Adm. 2012, 32, 4-23. [CrossRef]

20. Brunetto, Y.; Xerri, M.; Farr-Wharton, B.; Shacklock, K.; Farr-Wharton, R.; Trinchero, E. Nurse safety outcomes: Old problem, new solution-the differentiating roles of nurses' psychological capital and managerial support. J. Adv. Nurs. 2016, 72, $2794-2805$. [CrossRef] [PubMed]

21. Holtom, B.C.; Mitchell, T.R.; Lee, T.W.; Eberly, M.B. 5 turnover and retention research: A glance at the past, a closer review of the present, and a venture into the future. Acad. Manag. Ann. 2008, 2, 231-274. [CrossRef] 
22. Herold, D.M.; Lee, K.-H. The influence of internal and external pressures on carbon management practices and disclosure strategies. Australas. J. Environ. Manag. 2018, 26, 63-81. [CrossRef]

23. Fürst, E.W.M.; Herold, D.M. Fare Evasion and Ticket Forgery in Public Transport: Insights from Germany, Austria and Switzerland. Societies 2018, 8, 98. [CrossRef]

24. Goffnett, S.P.; Cook, R.L.; Williams, Z.; Gibson, B.J. Understanding satisfaction with supply chain management careers: An exploratory study. Int. J. Logist. Manag. 2012, 23, 135-158. [CrossRef]

25. Maloni, M.J.; Campbell, S.M.; Gligor, D.M.; Scherrer, C.R.; Boyd, E.M. Exploring the effects of workforce level on supply chain job satisfaction and industry commitment. Int. J. Logist. Manag. 2017, 28, 1294-1318. [CrossRef]

26. Wang, Y.; Yuan, H. What is behind high turnover: A questionnaire survey of hospital nursing care workers in Shanghai, China. BMC Health Serv. Res. 2018, 18, 485. [CrossRef] [PubMed]

27. Herold, D.M.; Nowicka, K.; Pluta-Zaremba, A.; Kummer, S. COVID-19 and the pursuit of supply chain resilience: Reactions and "lessons learned" from logistics service providers (LSPs). Supply Chain Manag. Int. J. 2021, 26, 702-714. [CrossRef]

28. Mikl, J.; Herold, D.M.; Ćwiklicki, M.; Kummer, S. The impact of digital logistics start-ups on incumbent firms: A business model perspective. Int. J. Logist. Manag. 2020, 32, 1461-1480. [CrossRef]

29. Herold, D.M.; Ćwiklicki, M.; Pilch, K.; Mikl, J. The emergence and adoption of digitalization in the logistics and supply chain industry: An institutional perspective. J. Enterp. Inf. Manag. 2021, 34, 1917-1938. [CrossRef]

30. Mikl, J.; Herold, D.M.; Pilch, K.; Ćwiklicki, M.; Kummer, S. Understanding disruptive technology transitions in the global logistics industry: The role of ecosystems. Rev. Int. Bus. Strat. 2020, 31, 62-79. [CrossRef]

31. Dobrovnik, M.; Herold, D.M.; Fürst, E.; Kummer, S. Blockchain for and in Logistics: What to Adopt and Where to Start. Logistics 2018, 2, 18. [CrossRef]

32. Hribernik, M.; Zero, K.; Kummer, S.; Herold, D.M. City logistics: Towards a blockchain decision framework for collaborative parcel deliveries in micro-hubs. Transp. Res. Interdiscip. Perspect. 2020, 8, 100274. [CrossRef]

33. Kummer, S.; Herold, D.M.; Dobrovnik, M.; Mikl, J.; Schäfer, N. A Systematic Review of Blockchain Literature in Logistics and Supply Chain Management: Identifying Research Questions and Future Directions. Futur. Internet 2020, 12, 60. [CrossRef]

34. Ahmed, S.; Kalsoom, T.; Ramzan, N.; Pervez, Z.; Azmat, M.; Zeb, B.; Rehman, M.U. Towards Supply Chain Visibility Using Internet of Things: A Dyadic Analysis Review. Sensors 2021, 21, 4158. [CrossRef]

35. Kassai, E.T.; Azmat, M.; Kummer, S. Scope of Using Autonomous Trucks and Lorries for Parcel Deliveries in Urban Settings. Logistics 2020, 4, 17. [CrossRef]

36. Vaidian, I.; Azmat, M.; Kummer, S. Impact of Internet of Things on Urban Mobility. In Proceedings of the Innovation Arabia 12, Dubai, United Arab Emirates, 24-27 February 2019.

37. Beirigo, B.A.; Schulte, F.; Negenborn, R.R. Integrating People and Freight Transportation Using Shared Autonomous Vehicles with Compartments. IFAC-PapersOnLine 2018, 51, 392-397. [CrossRef]

38. China Federation of Logistics \& Purchasing. China E-Commerce Logistics and Express Practitioners Survey Report 2017. Available online: http://www.cnnic.net.cn/gywm/xwzx/rdxw/20172017_7047/201808/t20180820_70486.htm (accessed on 7 September 2019).

39. Butts, M.M.; Vandenberg, R.J.; DeJoy, D.M.; Schaffer, B.S.; Wilson, M.G. Individual reactions to high involvement work processes: Investigating the role of empowerment and perceived organizational support. J. Occup. Health Psychol. 2009, 14, 122-136. [CrossRef]

40. Cooper, C.; Dewe, P.J.; O’Driscoll, M.P. Organizational Stress: A Review and Critique of Theory, Research, and Applications; Sage: Thousand Oaks, CA, USA, 2001. [CrossRef]

41. Choi, C.H.; Kim, T.T.; Lee, G.; Lee, S.K. Testing the stressor-strain-outcome model of customer-related social stressors in predicting emotional exhaustion, customer orientation and service recovery performance. Int. J. Hosp. Manag. 2014, 36, 272-285. [CrossRef]

42. Farr-Wharton, B.; Azzopardi, J.; Brunetto, Y.; Farr-Wharton, R.; Herold, N.; Shriberg, A. Comparing Malta and USA police officers' individual and organizational support on outcomes. Public Money Manag. 2016, 36, 333-340. [CrossRef]

43. Trinchero, E.; Borgonovi, E.; Farr-Wharton, B. Leader-member exchange, affective commitment, engagement, wellbeing, and intention to leave: Public versus private sector Italian nurses. Public Money Manag. 2014, 34, 381-388. [CrossRef]

44. Wright, T.A.; Bonett, D.G. The contribution of burnout to work performance. J. Organ. Behav.: Int. J. Ind. Occup. Organ. Psychol. Behav. 1997, 18, 491-499. [CrossRef]

45. Halbesleben, J.R.B.; Bowler, W.M. Emotional exhaustion and job performance: The mediating role of motivation. J. Appl. Psychol. 2007, 92, 93-106. [CrossRef]

46. Singh, J. Performance Productivity and Quality of Frontline Employees in Service Organizations. J. Mark. 2000, 64, 15-34. [CrossRef]

47. Zapf, D. Emotion work and psychological well-being: A review of the literature and some conceptual considerations. Hum. Resour. Manag. Rev. 2002, 12, 237-268. [CrossRef]

48. Harris, L.C.; Reynolds, K.L. Jaycustomer behavior: An exploration of types and motives in the hospitality industry. J. Serv. Mark. 2004, 18, 339-357. [CrossRef]

49. Chu, K.H.-L.; Murrmann, S.K. Development and validation of the hospitality emotional labor scale. Tour. Manag. 2006, 27, 1181-1191. [CrossRef] 
50. Dormann, C.; Zapf, D. Customer-related social stressors and burnout. J. Occup. Health Psychol. 2004, 9, 61. [CrossRef] [PubMed]

51. Chiang, F.F.; Birtch, T.A.; Kwan, H.K. The moderating roles of job control and work-life balance practices on employee stress in the hotel and catering industry. Int. J. Hosp. Manag. 2010, 29, 25-32. [CrossRef]

52. Huang, S.; van der Veen, R.; Song, Z. The impact of coping strategies on occupational stress and turnover intentions among hotel employees. J. Hosp. Mark. Manag. 2018, 27, 926-945. [CrossRef]

53. Lamm, F.; Lo, K. Occupational stress in the hospitality industry: An employment relations perspective. N. Z. J. Employ. Relat. 2005, 30, 23-47.

54. Mulvaney, R.H.; O’Neill, J.W.; Cleveland, J.N.; Crouter, A.C. A model of work-family dynamics of hotel managers. Ann. Tour. Res. 2007, 34, 66-87. [CrossRef]

55. Mobley, W.H.; Horner, S.O.; Hollingsworth, A.T. An evaluation of precursors of hospital employee turnover. J. Appl. Psychol. 1978, 63, 408. [CrossRef]

56. Hwang, J.; Lee, J.J.; Park, S.; Chang, H.; Kim, S.S. The impact of occupational stress on employee's turnover intention in the luxury hotel segment. Int. J. Hosp. Tour. Adm. 2014, 15, 60-77. [CrossRef]

57. O'Neill, J.W.; Davis, K. Work stress and well-being in the hotel industry. Int. J. Hosp. Manag. 2011, 30, 385-390. [CrossRef] [PubMed]

58. Jung, H.S.; Yoon, H.H.; Kim, Y.J. Effects of culinary employees' role stress on burnout and turnover intention in hotel industry: Moderating effects on employees' tenure. Serv. Ind. J. 2012, 32, 2145-2165. [CrossRef]

59. Frese, M.; Zapf, D. Action as the core of work psychology: A German approach. Handb. Ind. Organ. Psychol. 1994, 4, 271-340.

60. Katz, D.; Kahn, R.L. The Social Psychology of Organizations; Wiley New York: New York, NY, USA, 1978; Volume 2.

61. Semmer, N.; Zapf, D.; Greif, S. 'Shared job strain': A new approach for assessing the validity of job stress measurements. J. Occup. Organ. Psychol. 1996, 69, 293-310. [CrossRef]

62. Karatepe, O.M.; Uludag, O. Role stress, burnout and their effects on frontline hotel employees' job performance: Evidence from Northern Cyprus. Int. J. Tour. Res. 2007, 10, 111-126. [CrossRef]

63. Baron, R.A.; Neuman, J.H. Workplace violence and workplace aggression: Evidence on their relative frequency and potential causes. Aggress. Behav. Off. J. Int. Soc. Res. Aggress. 1996, 22, 161-173. [CrossRef]

64. Karatepe, O.M.; Yorganci, I.; Haktanir, M. Outcomes of customer verbal aggression among hotel employees. Int. J. Contemp. Hosp. Manag. 2009, 21, 713-733. [CrossRef]

65. Karatepe, O.M. Customer Aggression, Emotional Exhaustion, and Hotel Employee Outcomes: A Study in the United Arab Emirates. J. Travel Tour. Mark. 2011, 28, 279-295. [CrossRef]

66. Kashif, M.; Zarkada, A.; Thurasamy, R. Customer aggression and organizational turnover among service employees: The moderating role of distributive justice and organizational pride. Pers. Rev. 2017, 46, 1672-1688. [CrossRef]

67. Mathieu, C.; Babiak, P. Corporate psychopathy and abusive supervision: Their influence on employees' job satisfaction and turnover intentions. Pers. Individ. Differ. 2016, 91, 102-106. [CrossRef]

68. Michelle Rowe, M.; Sherlock, H. Stress and verbal abuse in nursing: Do burned out nurses eat their young? J. Nurs. Manag. 2005, 13, 242-248. [CrossRef] [PubMed]

69. Zapf, D.; Knorz, C.; Kulla, M. On the relationship between mobbing factors, and job content, social work environment, and health outcomes. Eur. J. Work. Organ. Psychol. 1996, 5, 215-237. [CrossRef]

70. Li, X.; Zhou, E. Influence of customer verbal aggression on employee turnover intention. Manag. Decis. 2013, 51, 890-912. [CrossRef]

71. Hsieh, A.; Yen, C.; Chin, K. Participative customers as partial employees and service provider workload. Int. J. Serv. Ind. Manag. 2004, 15, 187-199. [CrossRef]

72. Glaser, D.N.; Tatum, B.C.; Nebeker, D.M.; Sorenson, R.C.; Aiello, J.R. Workload and social support: Effects on performance and stress. Hum. Perform. 1999, 12, 155-176. [CrossRef]

73. Sager, J.K. A structural model depicting salespeople's job stress. J. Acad. Mark. Sci. 1994, 22, 74-84. [CrossRef]

74. Varca, P.E. Work stress and customer service delivery. J. Serv. Mark. 1999, 13, 229-241. [CrossRef]

75. Dollard, M.F.; LaMontagne, A.D.; Caulfield, N.; Blewett, V.; Shaw, A. Job stress in the Australian and international health and community services sector: A review of the literature. Int. J. Stress Manag. 2007, 14, 417-445. [CrossRef]

76. Kim, J.; Song, H.J.; Lee, C.-K. Effects of corporate social responsibility and internal marketing on organizational commitment and turnover intentions. Int. J. Hosp. Manag. 2016, 55, 25-32. [CrossRef]

77. Duraisingam, V.; Pidd, K.J.; Roche, A. The impact of work stress and job satisfaction on turnover intentions: A study of Australian specialist alcohol and other drug workers. Drugs: Educ. Prev. Policy 2009, 16, 217-231. [CrossRef]

78. Chen, M.-F.; Lin, C.-P.; Lien, G.-Y. Modelling job stress as a mediating role in predicting turnover intention. Serv. Ind. J. 2011, 31, 1327-1345. [CrossRef]

79. Qureshi, M.I.; Iftikhar, M.; Abbas, S.G.; Hassan, U.; Khan, K.; Zaman, K. Relationship between job stress, workload, environment and employees turnover intentions: What we know, what should we know. World Appl. Sci. J. 2013, 23, 764-770.

80. Hair, J.F.; Black, W.C.; Babin, B.J.; Anderson, R.E. Multivariate Data Analysis: A Global Perspective; Pearson Prentice Hall: Upper Saddle River, NJ, USA, 2011.

81. Farr-Wharton, B.; Shacklock, K.; Brunetto, Y.; Teo, S.T.T.; Farr-Wharton, R. Workplace bullying, workplace relationships and job outcomes for police officers in Australia. Public Money Manag. 2017, 37, 325-332. [CrossRef] 
82. Reynolds, K.L.; Harris, L.C. Deviant Customer Behavior: An Exploration of Frontline Employee Tactics. J. Mark. Theory Pr. 2006, 14, 95-111. [CrossRef]

83. Hui, C.; Lee, C.; Rousseau, D.M. Employment relationships in China: Do workers relate to the organization or to people? Organ. Sci. 2004, 15, 232-240. [CrossRef]

84. Chan, A.W.; Tong-Qing, F.; Redman, T.; Snape, E. Evaluating the multi-dimensional view of employee commitment: A comparative UK-Chinese study. Int. J. Hum. Resour. Manag. 2006, 17, 1873-1887. [CrossRef]

85. Chen, Z.X.; Tsui, A.S.; Farh, J.-L. Loyalty to supervisor vs. organizational commitment: Relationships to employee performance in China. J. Occup. Organ. Psychol. 2002, 75, 339-356. [CrossRef]

86. Redding, G. The Spirit of Chinese Capitalism; Walter de Gruyter: Berlin, Germany, 2013; Volume 22.

87. Wong, C.-S.; Wong, Y.-T.; Hui, C.; Law, K.S. The significant role of Chinese employees' organizational commitment: Implications for managing employees in Chinese societies. J. World Bus. 2001, 36, 326-340. [CrossRef]

88. Chang, H.-C.; Holt, G.R. Debt-Repaying Mechanism in Chinese Relationships: An Exploration of the Folk Concepts of Pao and Human Emotional Debt. Res. Lang. Soc. Interact. 1994, 27, 351-387. [CrossRef]

89. Hankookilbo. Emotional Labor Workers, though They Were Swore from Customers, They Apologized. 2011. Available online: http: //news.hankooki.com/ArticleView / ArticleView.php?url=society/201111/h2011112918411121950.htm\&ver=v002 (accessed on 23 January 2019).

90. Ben-Zur, H.; Yagil, D. The relationship between empowerment, aggressive behaviours of customers, coping, and burnout. Eur. J. Work. Organ. Psychol. 2005, 14, 81-99. [CrossRef]

91. Holmvall, C.M.; Sidhu, J. Predicting Customer Service Employees' Job Satisfaction and Turnover Intentions: The Roles of Customer Interactional Injustice and Interdependent Self-Construal. Soc. Justice Res. 2007, 20, 479-496. [CrossRef]

92. Walsh, G. Unfriendly customers as a social stressor-An indirect antecedent of service employees' quitting intention. Eur. Manag. J. 2011, 29, 67-78. [CrossRef] 